\title{
MAKING SENSE OF MESNE PROFITS: REMEDIES
}

\author{
CHARLES MITCHELL* AND LUKE ROSTILL**
}

\begin{abstract}
This is the second of two articles about cases in which awards of "mesne profits" have been made against defendants who have occupied claimants' land. The first article argues that the facts of cases where such awards have been made variously support claims in tort, contract or unjust enrichment and that practical consequences can flow from categorising the cases in one way or another. One is that different rules affect the assessment of remedies awarded to claimants depending on the claim that was made and the remedy that was awarded. The present article develops this point by examining the assessment principles governing "mesne profits" awards, according to whether these are classified as compensatory damages in tort, restitutionary damages in tort, orders that a defendant perform a contractual duty to pay a debt, compensatory damages for breach of contract, or orders that a defendant make restitution of an unjust enrichment.
\end{abstract}

KEYWORDS: mesne profits; remedies; damages; debt; restitution; trespass.

Word count: 15,329 (including footnotes), 11,873 (excluding footnotes).

\section{INTRODUCTION}

An "action for mesne profits" was originally an action in trespass for compensatory damages. It lay where one person (C) had a right to exclusive possession of land against another person (D) who had occupied the land in breach of C's right. Nowadays, a "claim for mesne profits" is understood more broadly than this: the term is still used to describe claims founded on the tort of trespass for compensatory damages, but it is now also used to describe claims founded on the tort of trespass for restitutionary damages and claims for certain other money awards where no trespass occurred because D had C's permission to occupy the land.

This is the second of two linked articles on this topic. In the first article we argue that several causes of action are variously disclosed by the facts of cases where "mesne profits" have been awarded and that these cases can be classified according to whether they concerned claims in tort, contract, or unjust enrichment. ${ }^{1}$ We argue that classifying the cases in this way makes it easier to see why "claims for mesne profits" lie in different situations, how such claims should be pleaded, what evidence must be produced for such claims to succeed, what remedies can be awarded to claimants and how these should be assessed. In the present article we develop

* Q.C. (Hon.), F.B.A., Professor of Law, University College London. Address for Correspondence: Bentham House, 4-8 Endsleigh Gardens, London WC1H OEG. Email: charles.mitchell@ucl.ac.uk.

*** Fellow and Tutor in Law at Trinity College, Oxford and Associate Professor of Property Law, Oxford University. Address for Correspondence: Trinity College, Oxford, OX1 3BH. Email: luke.rostill@law.ox.ac.uk. We thank Neeva Desai for her research assistance. For their detailed comments on drafts we thank Jessica Hudson and the anonymous CLJ referees. We presented an earlier version of this article as part of the Global Seminars in Private Law Theory and we thank the series organiser, Lionel Smith, and the seminar participants.

${ }^{1}$ C. Mitchell and L. Rostill, "Making Sense of Mesne Profits: Causes of Action" [2021] C.L.J. 130 . 
the last two points and discuss the rules governing the assessment of remedies awarded as "mesne profits". In our view, these rules are confused and widely misunderstood, and the main reason for this is that a single term - "mesne profits award" - is now used to describe several different remedies: compensatory damages in tort, restitutionary damages in tort, orders that a defendant should perform a contractual duty to pay a debt, compensatory damages for breach of contract, and orders that a defendant should make restitution of an unjust enrichment.

If this is correct, then it follows that an essential first step for anyone seeking to identify the assessment rules which govern "mesne profits awards" is to recognise that these divide into several remedies and to consider each remedy in turn. However, scant attention is paid to this in the modern "mesne profits cases", or in academic discussions of "mesne profits awards". The main project of this article is therefore to do the work of separately examining the rules affecting the assessment of such awards, conceived as compensatory or restitutionary damages for the tort of trespass by D (in Part II), as orders that D perform a contractual duty to pay C for the use and occupation of C's land or that D pay compensatory damages for breaching such a duty (in Part III), or as orders that D make restitution of an unjust enrichment gained at C's expense (in Part IV).

\section{DAMAGES FOR THE TORT OF TRESPASS}

\section{A. The Law before and after One Step}

The rules of assessment governing "mesne profits awards", conceived as damages for trespass, were affected by the Supreme Court's decision in One Step (Support) Ltd v Morris-Garner. ${ }^{2}$ This case was not itself concerned with a trespass to land, but with breaches of non-compete and non-solicit clauses in a contract for the sale of a business. In the Supreme Court, the central issue was when, if ever, a claimant is entitled to an award of "negotiating damages" for breach of contract, meaning damages assessed by reference to a hypothetical negotiation between the contracting parties, for such an amount as might reasonably have been demanded by the claimant for releasing the defendant from her duties. ${ }^{3}$ However, Lord Reed's judgment contains an important discussion of earlier cases concerning trespass to land where awards of "mesne profits" had been made, conceived as a type of damages known as "user damages". To explain how the law affecting tort-based claims for "mesne profits" has evolved, we shall therefore examine the "user damages" cases prior to One Step, discuss the Supreme Court's decision, and consider the ramifications of this not only for the assessment rules affecting future awards of such damages in trespass cases, but also for the rules affecting future awards of other types of damages for trespass and other money awards that do not respond to trespass.

The reason why we believe that Lord Reed's analysis has such wide implications is that we interpret his judgment to mean that the factual control of property is itself a benefit distinct from the profits of using property, that this benefit is capable of being measured in money terms, that claimants in trespass cases usually lose factual control of their property as a result of the defendant's wrong, and that the point of awarding "user damages" for trespass is to compensate claimants for this loss. In addition, and although Lord Reed does not say so himself, we consider that it follows from these propositions that the factual control of property is a benefit which can also be gained by defendants and that some (though not all) awards of restitutionary damages for trespass are best explained on this basis, as are some (though not all) awards of restitution for unjust enrichment where the defendant has occupied the claimant's land with permission.

\footnotetext{
${ }^{2}$ [2018] UKSC 20, [2019] A.C. 649.

${ }^{3}$ Ibid., at [23].
} 
Importantly, when we speak of "factual control" in this context, we are not referring to a legal right to control. Where, for example, $\mathrm{C}$ receives compensation for a loss of factual control resulting from D's trespass, the award does not compensate $\mathrm{C}$ for the loss of a right. ${ }^{4}$ Indeed, as we explained in our first article, C's claim for trespass against D is predicated on C having had a right to exclusive possession to the land during the period of the trespass, which right was infringed by $\mathrm{D}$. Ex hypothesi, therefore, D did not deprive $\mathrm{C}$ of this right.

Starting, then, with the law prior to One Step, the majority of cases in which the courts awarded "mesne profits", conceived as damages for trespass, were designed to compensate C for a loss of profits, i.e. they were based on the proposition that D's trespass caused C to lose profits that $\mathrm{C}$ would otherwise have obtained, most commonly by leasing the property to $\mathrm{D}$ or a third party. ${ }^{5}$ Indeed, this is how "actions for mesne profits" first acquired their name, ${ }^{6}$ although other types of loss could also be recovered, including lost profits that $\mathrm{C}$ would have made by using the land in some way other than letting it, e.g. farming it, ${ }^{7}$ the costs of a prior ejectment action by $\mathrm{C}$, according to cases predating the modern costs regime, ${ }^{8}$ and a diminution in the capital value of the land resulting from deterioration to its physical fabric while $\mathrm{C}$ was out of possession. ${ }^{9}$ All of these claims were governed by the rule that $\mathrm{C}$ could only recover "the loss which he [had] suffered in consequence of [D's] trespass", a "but for" test being applied to determine whether C's loss had been caused by D's tort. ${ }^{10}$ They were also subject to

\footnotetext{
${ }^{4}$ In this respect, our analysis differs from that of Mitchell McInnes, which seems to be centred on the idea that, in the relevant cases, $\mathrm{C}$ is deprived of a legal right to control a thing ("dominium"): M. McInnes, "Gain, Loss and the User Principle" [2006] R.L.R. 76, esp. 81, 85; criticised in C. Rotherham, "Wrotham Park Damages' and Accounts of Profits: Compensation or Restitution?" [2008] L.M.C.L.Q. 25, 42-47; K. Barker, "“Damages Without Loss': Can Hohfeld Help?" (2014) 34 O.J.L.S. 631, 640-41.

${ }^{5}$ As in e.g. Viscount Chelsea v Hutchinson (1996) 28 H.L.R. 17 (C.A.); Graves v Graves [2007] EWCA Civ 660, [2008] H.L.R. 10.

${ }^{6}$ Goodtitle v Tombs (1770) 95 E.R. 965, 967 (K.B.).

${ }^{7}$ Mortimer v Shaw (1922) 66 D.L.R. 311 (Saskatchewan C.A.).

${ }^{8}$ J.S. Saunders, The Law of Pleading and Evidence in Civil Actions (London 1828) vol. 2, 670; Symonds v Page (1830) 148 E.R. 1322 (Ex.); Bramley v Chesterton (1857) 140 E.R. 548 (C.P.). See too Anderson v Bowles (1951) 84 C.L.R. 310, 322.

${ }^{9}$ Different views have been expressed as to whether damages to compensate for a diminution in the capital value of the land count as awards of "mesne profits". Some judges have seemingly said that they do: e.g. Dunn v Large (1783) 99 E.R. 683; but others have treated them as falling outside the scope of this category: e.g. Ramzan v Brookwide Ltd [2011] EWCA Civ 985, [2012] 1 All E.R. 903, at [71] (Arden L.J.). See also Associated Deliveries Ltd. v Harrison (1984) 50 P. \& C.R. 91, 103-4 (Dillon L.J.) (C.A.); Nortask Pty. Ltd. v Areva Solar KCP Pty. Ltd. [2018] QSC 144, at [146]-[154]. This illustrates a general theme of our discussion, that the term "mesne profits" is ambiguous and imprecise and the law would do better without it. A related point is that, even at its broadest, the term "mesne profits" does not encompass the entire field of damages for trespass. For example, exemplary and aggravated damages are available as a remedy for trespass in appropriate cases, but have never been regarded as "mesne profits": see e.g. Horsford v Bird [2006] UKPC 3, [2006] 1 E.G.L.R. 75, at [14]; Ramzan v Brookwide [2011] EWCA Civ 985, at [80] (Arden L.J.).

${ }^{10}$ Ministry of Defence v Ashman (1993) 66 P. \& C.R. 195, 200 (Hoffmann L.J.) (C.A.). See too Mortimer v Shaw (1922) 66 D.L.R. 311, 312 (Lamont J.A.); Balanced Securities Ltd. v Bianco (No 2) [2010] VSC 201, (2010) 27 V.R. 599, at [16]; Cavenagh Investment Pte Ltd. v Kaushnik Rajiv [2013] SGHC 45, at [52].
} 
rules about remoteness and mitigation. ${ }^{11}$ All of these rules had been developed over many years and were well understood.

Two other groups of cases presented more difficulties, however. One concerned claims based on the tort of trespass for restitutionary damages, meaning damages designed to reverse D's gain rather than C's loss. Awards of restitutionary damages were of a more recent origin, ${ }^{12}$ and the cases, which were few, marked a departure from the view previously taken by some courts that such damages were not available for the tort of trespass. ${ }^{13}$ Hence, while the principle had been established that restitutionary damages were available for trespass, the rules affecting the quantification of D's gain for the purposes of such awards were underdeveloped.

The other group of cases concerned claims founded on the tort of trespass where damages had been awarded although $C$ had not pleaded, or had not demonstrated, either that $C$ had suffered any of the types of loss mentioned above or that D had obtained a profit from her use of the land. ${ }^{14}$ The awards made in these cases were commonly described as "user damages" and in an influential judgment, Nicholls L.J. averred that such awards were based on a "user principle" according to which "a person who has wrongfully used another's property without causing the latter any pecuniary loss may still be liable to that other for more than nominal damages." 15 The juridical nature of "user damages" was a murky question on which a variety of opinions were expressed by judges and scholars. Many of these were based on the assumption - which One Step has now held to be wrong - that $\mathrm{C}$ had not suffered any loss that could meaningfully be measured in money terms. ${ }^{16}$

Having made this assumption, some judges and scholars went on to argue that "user damages" were compensatory, but were designed to compensate $\mathrm{C}$ for "non-pecuniary" loss, meaning loss that was not measurable in money terms, unlike "pecuniary" loss, which was. ${ }^{17}$ On this view of "user damages", they were analogous to damages awarded in personal injury cases for loss of amenity: everyone agreed that $\mathrm{C}$ had sustained a loss but there was, and indeed

${ }^{11}$ Remoteness: Bramley v Chesterton (1857) 140 E.R. 548; Esperance Cattle Company Pty. Ltd. v Granite Hill Pty. Ltd. [2014] WASC 279, (2014) 47 W.A.R. 318, at [457]-[460]. Mitigation: Compatriot Holdings Ltd. v City Partnership Ltd. [2009] 3 E.G.L.R. 153 (County Ct), at [94]-[98]; and see too Hohepa v Piripi-Waima C30A [2019] NZMAC 8, at [41]-[46].

${ }^{12}$ Ministry of Defence $v$ Ashman (1993) 66 P. \& C.R. 195; Ministry of Defence $v$ Thompson (1993) 25 H.L.R. 552 (C.A.); Barrett v Morgan [1997] 1 E.G.L.R. 1; Shi v Jiangsu Native Produce Import \& Export Corp [2009] EWCA Civ 1582; Kwang v Yokkei [2016] C.C.J. 9 (A.J.), (2016) 88 W.I.R. 339.

13 e.g. Stoke-on-Trent C.C. v W. \& J. Wass Ltd. [1988] 1 W.L.R. 1406, 1415 (Nourse L.J.) (C.A.). Note that in Inverugie Investments Ltd. v Hackett [1995] 1 W.L.R. 713 (P.C.) the issue whether restitutionary damages should be available in trespass cases did not arise for decision, and was not considered by the court, because the point was not pleaded: ibid, at 715 . The case was therefore silent on the availability of restitutionary damages for trespass to land.

14 e.g. Whitwham v Westminster Brymbo Coal \& Coke Co. [1896] 2 Ch. 538 (C.A.); Swordheath Properties Ltd. v Tabet [1979] 1 W.L.R. 285 (C.A.).

15 Stoke-on-Trent C.C. $v$ Wass [1988] 1 W.L.R. 1406, 1416. See also Bocardo S.A. v Star Energy UK Onshore Ltd. [2010] UKSC 35, [2011] 1 A.C. 380, at [118]-[122] (Lord Clarke).The principle was also applied in cases involving property other than land e.g., Strand Electric and Engineering Co. Ltd. v Brisford Entertainments Ltd. [1952] 2 Q.B. 246 (C.A.).

${ }^{16}$ For an illustrative statement of this widely held view, see E. Cooke, "Trespass, Mesne Profits and Restitution" (1994) 110 L.Q.R. 420, 422.

${ }^{17}$ For a clear judicial statement of the distinction between loss which is susceptible of measurement in money and loss which is not, see Wright $v$ British Railways Board [1983] 2 A.C. 773, 777 (Lord Diplock) (H.L.). 
could be, no agreed yardstick against which the monetary value of this loss could be tested. "User damages" were therefore understood to differ from damages for loss of profits and damages for harm to the physical fabric of land, which were measurable in money terms. Many judges and scholars therefore began to say that compensatory damages for trespass divided into damages for "pecuniary loss", meaning damages for loss of profits or damages for physical damage to land, and damages for "non-pecuniary loss", meaning "user damages". As the law has developed, however, these labels have created some confusion, as we will see in a moment. Meanwhile, other judges and scholars said that "user damages" were not compensatory, but served another purpose: they said that "user damages" were restitutionary, i.e. that their point was to reverse a gain made by $\mathrm{D} ;{ }^{18}$ or that they "vindicated" C's right or provided a "substitute" for the non-infringement of this right; ${ }^{19}$ or that they were compensatory and restitutionary "hybrids" that somehow took into account both C's loss and D's gain in a manner that was not clearly explained. ${ }^{20}$

We will now turn to the One Step case. As we have said, the issue was whether and if so when "negotiating damages" can be awarded for breach of contract. The court held that they can, but only if the contractual duty breached by the defendant created or protected a valuable asset and the breach caused the claimant to lose that asset. The court also held that the purpose of such damages is to compensate the claimant for loss that is measurable in monetary terms. A crucial step in the court's reasoning was that the "user damages" awarded in earlier trespass cases had been designed to compensate for loss of this kind. ${ }^{21}$ Lord Reed noted that where D had "made valuable use" of C's land, without causing C to suffer "pecuniary loss", C has been "held to be entitled to damages measured as what a reasonable person would have paid for the right of user". ${ }^{22}$ After reviewing some relevant authorities, his Lordship went on to say: ${ }^{23}$

In these cases, the courts have treated user damages as providing compensation for loss, albeit not loss of a conventional kind. Where property is damaged, the loss suffered can be measured in terms of the cost of repair or the diminution in value, and damages can be assessed accordingly. Where on the other hand an unlawful use is made of property, and the right to control such use is a valuable asset, the owner suffers a loss of a different kind, which calls for a different method of assessing damages. In such circumstances, the person who makes wrongful use of the property prevents the owner from exercising his right to obtain the economic value of the use in question, and should therefore compensate him for the consequent loss.

In a subsequent passage, Lord Reed also said that the damages awarded in lieu of an injunction in Wrotham Park Estate Co. Ltd. v Parkside Homes Ltd. ${ }^{24}$ in which the defendants had built upon their land in breach of a restrictive covenant, "resembled the earlier cases in which user

18 e.g. A. Burrows, "Are 'Damages on the Wrotham Park Basis' Compensatory, Restitutionary or Neither?" in D. Saidov and R. Cunnington (eds.), Contract Damages: Domestic and International Perspectives (Oxford 2008).

19 e.g. R. Stevens, Torts and Rights (Oxford 2007), ch. 4.

${ }^{20}$ e.g. Inverugie Investments v Hackett [1995] 1 W.L.R. 713, 718.

${ }^{21}$ Affirmed Prudential Assurance Co. Ltd. v HMRC [2018] UKSC 39, [2019] A.C. 929, at [47].

22 [2018] UKSC 20, at [26]. Lord Reed's characterisation of C's position is expressed in language that we have already described as problematic, but we will defer discussion of this point for a moment more.

${ }^{23}$ Ibid., at [30].

${ }^{24}$ [1974] 1 W.L.R. 798 (Ch.). 
damages were awarded". ${ }^{25}$ For, just as a person who makes wrongful use of property "prevents the owner from exercising a valuable right to control its use", ${ }^{26}$ the refusal of an injunction in Wrotham Park "effectively deprived the plaintiffs of the benefit of their right", namely, "control" of "the use to which the defendants ... put their property". ${ }^{27}$ The purpose of the award in Wrotham Park was to compensate for this loss, and so it was akin to "user damages", the function of which was also to compensate claimants where the defendant's wrongdoing had caused them to lose control of their property.

Not everyone would agree with our reading of Lord Reed's analysis. First, some scholars might question our claim that Lord Reed regarded C's loss of factual control as the loss of a benefit that can be measured in money terms. ${ }^{28}$ It is true, as we have noted above, that Lord Reed said that C did not suffer a "pecuniary loss" in the "user damages" cases. ${ }^{29}$ However, his Lordship also said that control over property is usually a "valuable asset" and that, where $\mathrm{C}$ loses this asset, the loss can be measured by determining the economic value of the asset. ${ }^{30}$ How can one make sense of this? The answer, we suggest, is that when Lord Reed said that $\mathrm{C}$ had not suffered a "pecuniary loss", he did not mean to deny that $\mathrm{C}$ had suffered a loss that could be measured in money terms; rather, he meant to distinguish the loss of control which $\mathrm{C}$ had suffered from the loss suffered by claimants in cases where awards were made for loss of profits or for damage to the physical fabric of land - using the confusing labels which had emerged in the cases and scholarship to which we have already referred.

Secondly, Andrew Burrows's (extra-judicial) analysis of Lord Reed's speech identifies two possible interpretations of his Lordship's discussion, neither of which we agree with. According to Burrows, "Lord Reed effectively says that the relevant loss is the loss of the opportunity to obtain value or is the value of the right / asset of which the claimant has been deprived"; and in Burrows's view, "[t]he former equates to the 'loss of opportunity to bargain' analysis" and "[t]he latter seems to come close to the views of [Robert] Stevens that one is here valuing the right infringed". ${ }^{31}$ The "loss of opportunity to bargain" analysis mentioned here was originally advanced in a well-known article by Robert Sharpe and Stephen Waddams. ${ }^{32}$ On their account, where D wrongfully uses C's property, C "does suffer a real loss, namely, the opportunity to sell to [D] the right to use [C's] property" and "damages should be awarded to compensate [C] for this lost opportunity." "33 However, judges and scholars have objected to this on the basis that, in many of the relevant cases, ${ }^{34} \mathrm{C}$ had an opportunity to negotiate for the

${ }^{25}$ [2018] UKSC 20, at [54].

${ }^{26}$ Ibid., at [95].

${ }^{27}$ Ibid., at [54].

${ }^{28}$ Cf. E. Peel, "Negotiating Damages after One Step" (2019) 35 J.C.L. 216, 226.

29 [2018] UKSC 20, at [26].

${ }^{30}$ Ibid., at [30], [92], [95]. A passage in Lord Sumption's judgment gives rise to a similar problem of interpretation: [2018] UKSC 20, at [110].

31 A. Burrows, "One Step Forward?" (2018) 134 L.Q.R. 515, 518. See also A. Burrows, "Negotiating Damages" in C. Mitchell and S. Watterson (eds.), The World of Maritime and Commercial Law: Essays in Honour of Francis Rose (Oxford 2020), 300-303; P.S. Davies, "One Step Backwards: Restricting Negotiating Damages for Breach of Contract" [2018] L.M.C.L.Q. 433, 438; Josias Senu, "Negotiating Damages and the Compensatory Principle" (2020) 40 O.J.L.S. 110, 127-29.

${ }^{32}$ R.J. Sharpe and S.M. Waddams, "Damages for Lost Opportunity to Bargain" (1982) 2 O.J.L.S. 290.

${ }^{33}$ Ibid., at 290.

34 e.g. Penarth Dock Engineering Co. Ltd. v Pounds [1963] 1 Lloyd's Rep. 359 (Q.B.); Wrotham Park v Parkside [1974] 1 W.L.R. 798. 
grant of a licence and did not exploit it, or $\mathrm{C}$ had no such opportunity and would not have exploited it if she had because she would not have been willing or able to charge a fee to permit $\mathrm{D}$, or a third party, to use the property in the way D used it. ${ }^{35}$ On these facts, D's breach of duty did not deprive $\mathrm{C}$ of an opportunity to bargain or, if it did, the opportunity was of limited or no value to $\mathrm{C}$, because $\mathrm{C}$ would not have exploited it.

If, as Burrows argues, Lord Reed had embraced the "loss of opportunity to bargain" analysis in One Step, then his approach could be criticised on the same grounds. However, while some passages in Lord Reed's judgment might be read to support this interpretation of his analysis, ${ }^{36}$ the better view is that he did not conceive C's loss in the "wrongful use" cases as the loss of an opportunity to bargain, ${ }^{37}$ but conceived it as a loss of control over property. This is indicated by the passages of his judgment we have already quoted. ${ }^{38}$ It is also supported by his statement that, where the loss of an asset protected or created by the right that $D$ infringed is measured by reference to a hypothetical negotiation, this negotiation "is merely a tool for arriving at" the value of the asset. ${ }^{39}$ There is no suggestion here that $\mathrm{D}$, by breaching the duty, has deprived $C$ of an opportunity to bargain with $\mathrm{D}$ or a third party, or of the fee that $\mathrm{C}$ would have obtained through bargaining. Rather, the hypothetical negotiation is "merely a tool" for measuring the value of the benefit that $\mathrm{C}$ has lost, such as control of land or goods.

If this is right, then Lord Reed's view must also be distinguished from the view taken by Stevens, who has claimed that "user damages" and the damages awarded in Wrotham Park are both "substitutive" and "not compensatory for loss at all". ${ }^{40}$ Lord Reed unequivocally states that the awards made in all these cases are damages that compensate for loss. Where $\mathrm{C}$ is in possession of his land, and D enters and occupies it without C's permission, D deprives C of control of the land. Similarly, where D, without C's consent, takes C's horse from C and goes for a ride, $\mathrm{D}$ deprives $\mathrm{C}$ of control of the horse. The land may be undamaged; the horse may be "better for the exercise"; ${ }^{41}$ but C has still lost something which Lord Reed regarded as a benefit that can be measured in money terms, namely factual control of property. Lord Reed thus appears to have recognised, or to have come close to recognising, a point made in the scholarship. This is that $\mathrm{C}$ has an interest in deciding what is done with the property, and by whom. In Nicholas McBride's words, when D goes for a ride on C's horse without C's permission, D deprives $\mathrm{C}$ of "the freedom to decide for himself who gets to ride on the horse and who doesn't." 42

${ }^{35}$ See e.g. Surrey C.C. v Bredero Homes Ltd. [1993] 1 W.L.R. 1361, 1369 (Steyn L.J.) (C.A.); Marathon Asset Management LLP v Seddon [2017] EWHC 300 (Comm.), [2017] 2 C.L.C. 182, at [195]-[196] (Leggatt J.); J. Edelman, Gain-Based Damages: Contract, Tort, Equity and Intellectual Property (Oxford 2002), 99-103; Rotherham, “'Wrotham Park Damages' and Accounts of Profits: Compensation or Restitution?", 31-35.

${ }^{36}$ e.g. [2018] UKSC 20, at [30]: "the person who makes wrongful use of the property prevents the owner from exercising his right to obtain the economic value of the use in question".

${ }^{37}$ Cf. W. Day, "Restitution for Wrongs: One Step Forwards, Two Steps Back" [2018] R.L.R. 60,65 .

${ }^{38}$ See also [2018] UKSC 20, at [69], [76], [79], [83]-[84], [89], [92]-[93].

${ }^{39}$ Ibid., at [91].

${ }^{40}$ Stevens, Torts and Rights, 62.

${ }^{41}$ Watson, Laidlaw, \& Co. Ltd. v Pott, Cassels, \& Williamson 1914 S.C. (H.L.) 18, 31 (Lord Shaw).

${ }^{42}$ N. McBride, "Restitution for Wrongs" in C. Mitchell and W. Swadling (eds.), The Restatement Third: Restitution and Unjust Enrichment (Oxford 2013), 274. See also J. Raz, "Rights and Individual Well-Being" in his Ethics in the Public Domain (Oxford 1995), 48-49; J. Edelman, "The Meaning of Loss and Enrichment" in R. Chambers et al (eds.), Philosophical 
What are the implications of all this for "mesne profits awards", conceived as damages for trespass to land? One is that the cases must now be understood to fall into two groups only: cases where compensatory damages are awarded and cases where restitutionary damages are awarded. There is no third group of cases in which some other kind of damages are awarded. Hence the awards of "user damages" made prior to One Step must have been compensatory or restitutionary, and we believe that most, if not all, of them must have been compensatory because they responded to C's loss of factual control of the land. ${ }^{43}$

Can cases be identified in which awards of "mesne profits" have been made which were conceived as awards of restitutionary damages and which responded to D's gain of control? The answer is yes. Some such awards have aimed to strip D of profits acquired by wrongfully using C's property, ${ }^{44}$ but the idea that control of land is a distinct benefit, the value of which can alternatively form the basis of a restitutionary damages award, was central to Ministry of Defence $v$ Ashman. ${ }^{45}$ Mrs Ashman's husband was in the RAF and they jointly occupied MOD housing for which they paid rent at a concessionary rate. They separated and he left the property. Her permission to occupy the house was withdrawn, but she stayed there because the local authority failed to rehouse her immediately. Once this had been done, the MOD sued her for trespass and sought an award of "mesne profits", calculated not by reference to its loss of profits, which would have been the amount of concessionary rent it would have charged another tenant, but by reference to her gain. ${ }^{46}$ Hoffmann L.J. said that the MOD "elected for the restitutionary remedy" and was entitled to damages assessed by reference to "the value of the benefit which the [defendant] has received". ${ }^{47}$ Similarly, Kennedy L.J. averred that the MOD was entitled to receive as damages "the proper value to Mrs. Ashman of the use of the property". ${ }^{48}$ Mrs Ashman did not obtain any profits as a result of her occupation, but she did obtain a different benefit: control of the land, which she exploited by residing in the property.

The editors of McGregor on Damages would disagree with our analysis of Ashman, since they say that the case "must now be treated as wrongly decided", the reason being that One Step holds that "user damages" are "compensatory, not restitutionary" ${ }^{49}$ However, this argument starts from a false premise: that all "mesne profits awards", conceived as damages

Foundations of the Law of Unjust Enrichment (Oxford 2009), 215. It is important to distinguish the view that, in the relevant cases, $\mathrm{C}$ lost factual control of a thing from two similar, but significantly different, loss-oriented explanations: first, that $\mathrm{C}$ lost the opportunity of obtaining an injunction to prevent the wrong: Tamares (Vincent Square) Ltd. v Fairpoint Properties (Vincent Square) Ltd. [2007] EWHC 212 (Ch.), [2007] 1 W.L.R. 2167, [3]-[6], [22] (Gabriel Moss Q.C.); secondly, that C lost the legal power to obtain, or to trigger the court's jurisdiction to award, injunctive relief to prevent the wrong: Barker, "Damages Without Loss': Can Hohfeld Help?".

43 e.g. Whitwham v Westminster Brymbo Coal [1896] 2 Ch. 538; Swordheath Properties $v$ Tabet [1979] 1 W.L.R. 285. We think that Inverugie Investments v Hackett [1995] 1 W.L.R. 713 was a restitutionary damages case but space does not allow us to make this argument here. ${ }^{44}$ Kwang v Yokkei [2016] C.C.J. 9 (A.J.), at [11], [56]. See also Barrett v Morgan [1997] 1 E.G.L.R. 1, 1, where the trial judge seems to have accepted that such an award was available in principle but held that there had been no trespass; the latter finding was affirmed by the C.A.: [1999] 1 W.L.R. 1109; but reversed by the H.L.: [2000] 2 A.C. 264.

45 (1993) 66 P. \& C.R. 195. See also Ministry of Defence $v$ Thompson (1993) 25 H.L.R. 552.

46 The proceedings were brought on the assumption that the local authority, rather than Mrs Ashman herself, would pay the amount of the award made against her.

47 (1993) 66 P. \& C.R. 195, 200-201.

${ }^{48}$ Ibid., at 199.

${ }^{49}$ J. Edelman et al (eds.), McGregor on Damages (21 ${ }^{\text {st }}$ edn., 2021), at paras 39-054-39-055. 
for trespass, are awards of "user damages". The reasoning goes that because all awards of "user damages" must now be seen as compensatory, all "mesne profits awards" that were conceived by the courts as awards of restitutionary damages must be recharacterized as compensatory. However, as we have explained above, awards of "user damages" have never been understood to include every type of "mesne profits award", and there is no indication in Lord Reed's judgment that he took such a broad view of the cases falling into the "user damages" category. Ashman was not cited in argument in One Step and is not referred to in any of the judgments. Moreover, the editors of McGregor do not suggest that the effect of One Step is to prevent C from recovering the profits $\mathrm{D}$ has derived from using the property, but it is difficult to see why, in principle, restitutionary damages should be available in respect of this kind of gain but not where the gain acquired by $\mathrm{D}$ is factual control of property. For these reasons, we do not agree that One Step should be seen as having overruled Ashman sub silentio.

To sum up, we have argued that One Step contains an important insight: that factual control of property is a benefit which is distinct from the profits which a claimant could have made from using property. ${ }^{50}$ Control of property is usually lost by claimants in cases where D has occupied C's land as a trespasser and in principle this loss is measurable in money terms, albeit that in some rare cases the value of the loss is zero. ${ }^{51}$ Claimants in trespass cases who have lost profits may therefore have a choice respecting the loss in respect of which they can claim compensatory damages: they can claim damages for loss of profit or they can claim damages for loss of control. These are not the same and it needs to be clear which type of loss forms the subject of a claim for compensatory damages before the loss is valued. The rules of assessment which govern this process are considered in Part IIB.

The corollary of these propositions is that control of property is always gained by defendants in trespass cases, that this is not the same benefit as profits made by defendants from using property, and so again it needs to be clear which type of gain forms the subject of a claim for restitutionary damages before the gain is valued. These rules governing this process are discussed in Part IIC. Note, finally, that the same distinction between these two benefits must also be drawn in claims for unjust enrichment before valuing D's gain. The valuation rules governing this process are examined in Part IV.

\section{B. Compensatory Damages}

As we have said, most awards of "mesne profits" responding to the tort of trespass, and conceived as awards of compensatory damages, aim to compensate $\mathrm{C}$ for loss of rental income. The starting point for quantifying such claims is to identify the market rental value of the property. ${ }^{52}$ Where the trespass began following the termination of a lease held by $\mathrm{D}$, and/or ended when $\mathrm{C}$ granted $\mathrm{D}$ a new lease, the rent payable by $\mathrm{D}$ under the old or new lease may well be relevant evidence showing what $\mathrm{C}$ would have received if she had let the property during the period of D's trespass. ${ }^{53}$ Where $\mathrm{D}$ has never had a lease, reference can be made to

\footnotetext{
${ }^{50}$ In our first article on "mesne profits", we use different language to refer to what we describe here as "factual control of property", speaking there of the "opportunity to use property". This is merely a terminological difference and the two labels refer to the same thing.

${ }^{51}$ In One Step, Lord Reed recognised that the control of property is not always a "valuable asset": [2018] UKSC 20, at [30], [95]; and on the unusual facts of some cases it is worth nothing, e.g. Wigan B.C. v Scullindale Global Ltd. [2021] EWHC 779 (Ch.).

${ }^{52}$ Viscount Chelsea v Hutchinson (1996) 28 H.L.R. 17, 19 (C.A.); Graves v Graves [2007] EWCA Civ 660, at [44]-[53].

${ }^{53}$ Lamru Pty. Ltd. v Kation Pty. Ltd. (1998) 44 N.S.W.L.R. 432, 439 (N.S.W.S.C.); Rock Bottom Fashion Market Pty. Ltd. (in liq.) v H.R. \& C.E. Griffiths Pty. Ltd. [1998] QCA 123,
} 
rent paid by another person who occupied the property before or after $\mathrm{D},{ }^{54}$ or to the open market rates charged for analogous premises, in which case care must be taken to identify appropriate comparators. ${ }^{55}$ In all of these cases, adjustments may be needed to reflect agency fees, market fluctuations, and changes in the condition of the land affecting its rental value. ${ }^{56}$ Special considerations also arise in cases where a co-owner of property, $\mathrm{C}$, has been wrongfully ousted by another co-owner, D: ${ }^{57}$ in an Australian case of this kind, Biviano v Natoli, ${ }^{58}$ it was held that $\mathrm{C}$ could recover compensation for loss of market rental value from $\mathrm{D}$, but that the rent $\mathrm{C}$ would have charged should be calculated on the basis that $\mathrm{D}$ would (legitimately) have continued to occupy the property at the same time - meaning that a reduction of $50 \%$ or more would usually be appropriate. ${ }^{59}$

The editors of Woodfall write that an assessment of rental value should be undertaken "on the basis of a short term letting at a rack rent on the terms which would in practice form the terms on which the landlord would let". ${ }^{60}$ This proposition was endorsed in a Hong Kong case, Bonnie Blair Ltd. $v$ Witmore Ltd. ${ }^{61}$ where the judge stressed that it "is capable of accommodating any adjustments in rental value in case the tenant held over as a trespasser for a prolonged period of time", but added that what "constitutes 'a short-term letting' on terms which the landlord would let is ... not to be defined inflexibility [sic.], it is a case-specific issue to be decided in each case after taking into account all the relevant circumstances". ${ }^{62}$ The Bonnie Blair case concerned industrial units, and the judge found that "tenants of this type of property would look for some continuity in occupation", ${ }^{63}$ with the result that:

the usual tenure the defendants would let at rack rent for the two subject premises would be about 2 to 3 years. Therefore, I find that the assessment of mesne profits shall be done by reference to a two-year lease rather than a succession of half-yearly ones.

[1998] A.N.Z. Conv. R. 549; Jones v Merton L.B.C. [2008] EWCA Civ 660, [2009] 1 W.L.R. 1269, at [24] (Wilson L.J.); Sze Tu v Jam Studios Pty. Ltd. (No. 2) [2018] NSWSC 1611, at [20]-[23].

${ }^{54}$ Lau Wing Keung v Ng Ah Kui [1984] HKCA 238, [1984] H.K.L.R. 241; Puhinui Farms Ltd. $v$ I..H. Wedding \& Sons Ltd. [2008] NZHC 130, at [205].

${ }^{55}$ Earlrose Golf \& Leisure Ltd. v Fair Acre Investments Ltd. [2009] EWCA Civ 1295; Curry $v$ HSBC Bank Plc [2021] NICh 1, at [60]-[61] and [64] (C's expert evidence as to market rental value of property rejected because comparison drawn with property elsewhere). Identifying relevant comparators may be impossible in which case a different approach must be taken, as in e.g. Queenstown Central Ltd. v March Construction Ltd. [2016] NZHC 1884.

${ }^{56}$ Graves v Graves [2007] EWCA Civ 660, at [48]; Woodley v Woodley [2018] WASC 333, at [102]; Baynton-Williams v Baynton-Williams [2020] EWHC 625 (Ch.).

${ }^{57}$ In the absence of wrongful ouster, no claim lies between co-owners for "mesne profits" conceived as damages for trespass: Cheung Lai Mui v Cheung Wai Shing [2021] HKFCA 19. 58 (1998) 43 N.S.W.L.R. 695, 704 (N.S.W.C.A.); noted H. Conway, "Co-owners, Ouster and Occupation Fees" [2000] Conv. 49. See also E. Cooke, "Equitable Accounting” [1995] Conv. 391, 402.

${ }^{59}$ Lyko v Derkatch [2018] SADC 90, at [716]; Burton v Prior [2019] NSWSC 518, at [275][280].

${ }^{60}$ The Hon. Lord Justice Lewison et al. (eds.), Woodfall, Landlord and Tenant (London, 2020 release) vol. 1, para. 19.013.1.

${ }^{61}$ [2015] HKDC 87, [2015] 2 H.K.C. 482, at [23].

${ }^{62}$ Ibid., at [24].

${ }^{63}$ Ibid., at [26]. 
Moreover, had the defendants and plaintiff committed on a lease of 2 years, they would not have been affected by any subsequent increases or decrease in rental value. ${ }^{64}$

Where the market value of premises wrongfully occupied by D is lower than the rent formerly paid by $\mathrm{D}$ under a lease, the market rate is the amount of C's loss and she can recover no more than this as compensatory damages. ${ }^{65}$ In Clifton Securities Ltd. v Huntley, however, Denning J. said that where the rent previously payable by D under a lease still represents the market value of the premises, "mesne profits are assessed at the amount of the rent" and "if the real value is higher than the rent, then the mesne profits must be assessed at the higher value". ${ }^{6}$ These dicta were followed in another Hong Kong case, Wharf Properties Ltd. v Fu On Trading Co. Ltd. ${ }^{67}$ where D's wrongful occupation of one part of C's property had prevented C from letting the whole of the property to a third party. D was liable for the whole of C's resulting loss, the basis on which $\mathrm{C}$ had intended to re-let the property having been known to $\mathrm{D}$ and C's loss therefore having been reasonably foreseeable and so not too remote to be recovered. ${ }^{68}$

Where the market rental value of land is diminished as a result of D's wrongful actions, D cannot rely on this fact to argue that the damages for which she is liable should be reduced. This point arose in Shepherd v Collect Investments Ltd. ${ }^{69}$ where D had permitted third parties to dump waste on C's property, and David Richards L.J. averred that D could not "seek to reduce the amount of lost rental by reference to the presence of waste for which he [was himself] responsible". ${ }^{70}$ According to the editors of McGregor, the converse proposition also holds good: they state that if $\mathrm{D}$ "makes improvements on the land, the rental value should be assessed upon the unimproved value", noting that:

The land itself will of course be recovered in its improved state, and there is no clear machinery whereby the claimant may be made to pay for these improvements even if there are sufficient damages for wrongful occupation from which the value of the improvements could be deducted. ${ }^{71}$

Given the difficulties which have historically been faced by occupiers who improve the land in the mistaken belief that they are or will become the owners, ${ }^{72}$ this has an appealing fairness

\footnotetext{
${ }^{64}$ Ibid., at [28].
}

${ }^{65}$ Medi-Aid Centre Foundation Ltd. v Joys Child Care Ltd. (No. 2) [2019] NSWSC 1105, at [45], endorsing B. Edgeworth, Butt's Land Law (7th edn., Sydney 2017), para. 7.1570.

66 [1948] 2 All E.R. 283, 284 (K.B.). Cf. Progressive Mailing House Pty. Ltd. v Tabali Pty. Ltd. (1985) 157 C.L.R. 17, 39 (Brennan J.).

${ }^{67}$ [1989] HKCA 288, [1989] 2 H.K.C. 54, at [20]-[21]. See also Barclays Bank Ltd. (Trustees of G.F. Day, deceased) v Jones [1955] J.P.L. 822; Lau Wing Keung v Ng Ah Kui [1984] H.K.L.R. 241.

${ }^{68}$ Ibid., at [23]. See too Henderson v Squire (1869) L.R. 4 Q.B. 170, 173 (Cockburn C.J.); Barclays Bank Ltd. v Jones [1955] J.P.L. 822.

${ }^{69}$ [2018] EWCA Civ 162.

${ }^{70}$ Ibid., at [21].

${ }^{71}$ McGregor on Damages, para. 39.046, n. 265. In Pickering v Hughes [2021] EWHC 1672 (Ch.) an argument of this kind was rejected but one reason for this was that different improvements had been made to the property by different parties.

${ }^{72}$ Tang Hang Wu, "An Unjust Enrichment Claim for the Mistaken Improver of Land" [2011] Conv. 8, and the literature cited at 21, n. 61; he argues that a claim in unjust enrichment should now be recognised, but there is no sign of this in the English cases. Cf. Montreuil v Ontario Asphalt Co. (1922) 63 S.C.R. 401 (Sup. Ct. of Canada), esp. at [100]-[106]; Lollis v Loulatzis 
and a rule of this sort can be found in the Compulsory Purchase Act 1965, s. 22(4). ${ }^{73}$ The idea that awards should be reduced to reimburse $\mathrm{D}$ for expenditure from which $\mathrm{C}$ derives a benefit also finds expression in court orders that deductions from awards of damages should be made to take account of expenses incurred by $\mathrm{D}$ that $\mathrm{C}$ would have paid herself if she had occupied the property during the relevant period, e.g. tax payments. ${ }^{74}$

Where $\mathrm{C}$ seeks compensation for losing factual control of the land, how is the monetary value of this loss to be quantified? In One Step Lord Reed averred that "[t]he court will have to select the method of measuring the loss which is the most apt in the circumstances to secure that the claimant is compensated for the loss which it has sustained" ${ }^{75}$ This statement was made in the context of a discussion of damages for breach of contract, but Lord Reed clearly did not intend it to be confined to that context. ${ }^{76}$ Where D has wrongfully occupied C's land, a common approach is to measure C's loss of control by reference to the market rental value of the property. In Swordheath Properties Ltd. v Tabet ${ }^{77}$ for example, the Court of Appeal held that $\mathrm{C}$ can recover the market rental value of the land in cases where there is no evidence that $\mathrm{C}$ would or could have let it. In some other cases, however, the courts have measured C's loss by reference to a hypothetical negotiation. ${ }^{78}$ They have, in other words, awarded "negotiating damages". So the questions arise: when should a court use this method of quantification? And will the selection of one method over another significantly affect the size of the award? To answer these questions, we must consider negotiating damages in more detail.

In One Step Lord Reed said that negotiating damages are "arrived at by reference to the amount which the claimant might reasonably have demanded as a quid pro quo for the relaxation of the obligation in question". ${ }^{79}$ They are assessed on the basis of a hypothetical negotiation between a "willing buyer" and a "willing seller" in which the subject-matter of the negotiation is the release of the relevant obligation, and "[b]oth parties are to be assumed to act

[2007] VSC 547, at [230] - both cases in which a mistaken improver was permitted to set off the cost of improvements against liability for mesne profits, but not to recover any excess. And cf. M. McInnes, "Improvements to Land, Equity, Proprietary Estoppel and Unjust Enrichment" (2016) 2 Canadian Journal of Comparative and Contemporary Law 421, arguing that Canadian law should allow claims in unjust enrichment for the whole amount.

${ }^{73}$ See too Indian Code of Civil Procedure 1908, s. 2(12); Burrell v Humphrey [1951] N.Z.L.R. 262. And cf. Palmer v Lane [2001] EWCA Civ 1670, at [4]-[5], considering but not deciding whether a reduction should be made to reflect the fact that $\mathrm{C}$ had benefited from a rise in the capital value of her house occasioned by market movements during D's occupation.

${ }^{74}$ Barber v Brown (1856) 140 E.R. 50, 64 (Creswell J.), approving Doe v Hare (1833) 149 E.R. 709, 709 (Bayley B.); both noted in Hampton v BHP Billiton Minerals Pty. Ltd. (No 2) [2012] WASC 285, at [339] (Edelman J.). But cf. Bonnie Blair v Witmore [2015] HKDC 87, at [35], observing that nowadays there are often no fixed rules as to who out of a landlord and tenant should bear the cost of taxes and management fees and hence that this is "generally a matter of negotiation".

75 [2018] UKSC 20, at [37].

76 Ibid., at [63], [70], [95].

77 [1979] 1 W.L.R. 285 (C.A.). See also Brynowen Estates Ltd. v Bourne (C.A., 21 October 1981); Shi v Jiangsu Native Produce Import \& Export Corp [2009] EWCA Civ 1582, at [19], [24] (Dyson L.J.). Cf. Horsford v Bird [2006] UKPC 3, [2006] 1 E.G.L.R. 75, at [12]-[13].

${ }^{78}$ Severn Trent Water Ltd. v Barnes [2004] EWCA Civ 570; Field Common Ltd. v Elmbridge B.C. [2008] EWHC 2079 (Ch.), [2009] 1 P. \& C.R. 1; Stadium Capital Holdings (No 2) Ltd. v St Marylebone Property Co. PLC [2011] EWHC 2856 (Ch.), [2012] 1 P. \& C.R. 7.

${ }^{79}$ [2018] UKSC 20, at [95]. See also Wrotham Park v Parkside [1974] 1 W.L.R. 798, 815. 
reasonably" ${ }^{80}$ In One Step, Lord Carnwath accepted that, where negotiating damages are awarded as a remedy for trespass, it should be assumed that the hypothetical negotiation took place at the time the infringement began. ${ }^{81}$ Lord Reed was "inclined to agree", though he chose not to express a concluded view as it was not a live issue in the case, ${ }^{82}$ and this was the approach taken in Stadium Capital Holdings (No 2) Ltd v St Marylebone Property Co. PLC. ${ }^{83}$

Where the hypothetical negotiation is assumed to occur at the time the infringement began, the sum that the parties, acting reasonably, would agree to pay/accept depends, in part, on their reasonable expectations as to the benefits they will obtain and the detriments they will incur. ${ }^{84}$ In Field Common Ltd. v Elmbridge B.C. ${ }^{85}$ Warren J. noted that an award of negotiating damages might well differ in quantum from an award of damages designed to make $\mathrm{D}$ disgorge profits from using the land, albeit that the amount of these profits might retrospectively serve as evidence of the amount that reasonable people in C's and D's position would have agreed that $\mathrm{D}$ should pay $\mathrm{C}$ when the trespass began. The sum that would be agreed in the hypothetical negotiation will also partly depend on the options available to a reasonable person in D's position - on whether there are other ways for her to achieve her ends, or whether the other party holds a "trump card". ${ }^{86}$ However, it is not permissible for a court to conclude that, since D could have lawfully achieved her ends without reaching an agreement with the claimant, no price at all would have been agreed in the negotiations. ${ }^{87}$

Where D has wrongfully occupied C's land, and C seeks to recover damages in trespass in respect of her loss of control of the land, when is it appropriate to quantify the loss on the basis of a hypothetical negotiation? In Field Common, Warren J. said that "where a landlord seeks mesne profits in an ordinary case of holding over without consent, the basis of assessment is generally the open market rental value of the property" and for this reason there is usually no need for a court to consider an award of negotiating damages. ${ }^{88}$ In Enfield L.B.C. v Outdoor Plus, however, Henderson J. added that the "hypothetical negotiation approach" would be the right one for a court to adopt in those rare cases where "there is no established market rate for the letting of [the relevant property]". ${ }^{89}$ In Marathon Asset Management LLP $v$ Seddon, ${ }^{90}$

${ }^{80}$ Pell Frischmann Engineering Ltd. v Bow Valley Iran Ltd. [2009] UKPC 45, [2011] 1 W.L.R. 2370, at [49]. See also One Step v Morris-Garner [2018] UKSC 20, at [75] (Lord Reed).

${ }^{81}$ [2018] UKSC 20, at [159]. See also Lunn Poly Ltd. v Liverpool \& Lancashire Properties Ltd. [2006] EWCA Civ 430, [2006] 2 E.G.L.R. 29, at [17]-[37] (Neuberger L.J.); Pell Frischmann v Bow Valley [2009] UKPC 45, at [50]-[51].

${ }^{82}$ Ibid., at [56].

83 [2011] EWHC 2856 (Ch).

${ }^{84}$ Wrotham Park v Parkside [1974] 1 W.L.R. 798, 815-16; Pell Frischmann v Bow Valley [2009] UKPC 45, at [51]; Jones $v$ Ruth [2011] EWCA Civ 804, [2012] 1 W.L.R. 1495, at [39][41]; Stadium Capital Holdings v St Marylebone Property [2011] EWHC 2856 (Ch), at [69], [78]-[84].

85 [2008] EWHC $2079(\mathrm{Ch})$, at [77]-[79].

${ }^{86}$ Sinclair v Gavaghan [2007] EWHC 2256 (Ch), at [16]-[17]; Stadium Capital Holdings v St Marylebone Property [2011] EWHC 2856 (Ch), at [69], [78]-[84]; Enfield L.B.C. v Outdoor Plus Ltd. [2012] EWCA Civ 608, [2012] 2 E.G.L.R. 105, at [51].

${ }^{87}$ Enfield L.B.C. v Outdoor Plus [2012] EWCA Civ 608. Note, though, that "the premise of the hypothetical negotiation ... breaks down in a situation where any reasonable person in the claimant's position would have been unwilling to grant a release": One Step v Morris-Garner [2018] UKSC 20, at [75] (Lord Reed).

88 [2008] EWHC 2079 (Ch.), at [77].

${ }^{89}$ [2012] EWCA Civ 608, at [53].

90 [2017] EWHC 300 (Comm.). 
Leggatt J. said that where a wrongdoer has used "property which can be bought or hired in a market", the "benefit can then be valued on the basis of the market price", ${ }^{91}$ but where there is no market, it may be "appropriate to value the benefit obtained by the defendant by estimating the licence fee that would reasonably have been charged" ${ }^{92}$ Leggatt J. regarded negotiating damages as "restitutionary" in the sense that they are always "assessed by valuing a gain made by the defendant", ${ }^{93}$ and in this respect his judgment has been overtaken by One Step, which suggests that they are compensatory. Howerver, the proposition that it is appropriate to use the "hypothetical negotiation" measure where there is no market rate for factual control of land lost by a claimant is consistent with One Step and in line with the views expressed by judges in other cases, including Enfield. ${ }^{94}$

\section{Restitutionary Damages}

A claim based on the tort of trespass for restitutionary damages differs from a claim in unjust enrichment for restitution. This is not always understood because the two remedies both focus on D's gain. The potential for confusion was also created by Hoffmann L.J.'s description of the claim in Ministry of Defence $v$ Ashman ${ }^{95}$ as a "claim in restitution". When his judgment is read as a whole, it is clear he meant a claim founded on the tort of trespass for restitutionary damages, ${ }^{96}$ but he could be misread as having meant "a claim in unjust enrichment". 97

Different quantification rules govern awards of restitutionary damages for trespass and awards of restitution of unjust enrichment. Application of these rules to some facts will produce the same outcome and, indeed, the same outcome as application of the quantification rules affecting compensatory damages for trespass. For example, where the gain acquired by $\mathrm{D}$ was control of C's land, the starting point for valuation is to identify the land's market rental value, whether the claim is for restitutionary damages in tort or for restitution of an unjust enrichment, and as we have discussed, this is also the starting point for valuing C's loss of control for the purposes of an award of compensatory damages. ${ }^{98}$ Unless there are reasons to value D's gain and/or C's loss differently, the sum awarded in all these cases will therefore be the same. ${ }^{99}$ Application of the assessment rules to other facts can produce different outcomes, however. For example, in Ministry of Defence $v$ Thompson, where a claim based on trespass was made for restitutionary damages, Hoffmann L.J. said it was "irrelevant to the calculation of the benefit" received by $\mathrm{D}$ (which was control of the land) that $\mathrm{C}$ would have let the premises "at a concessionary rent, or even would not have let them at all", although this would have affected

\footnotetext{
91 Ibid., at [232].

92 Ibid., at [233].

${ }^{93}$ Ibid., at [199].

${ }^{94}$ See also Whitwham $v$ Westminster Brymbo Coal [1896] 2 Ch. 538, 543-44 (Rigby L.J.) and discussion of this case in Peel, "Negotiating Damages after One Step", 217-18. Cf. McGregor on Damages, paras 14-039-14-042, 39-049-39-050.

95 (1993) 66 P. \& C.R. 195, 201.

${ }^{96}$ Confirmed by Lord Clarke in Benedetti v Sawiris [2013] UKSC 50, [2014] A.C. 938, at [24].

${ }^{97}$ Cf. Twin Benefits Ltd. v Barker [2017] EWHC 1412 (Ch.), at [108]: 'A restitutionary claim - a claim for unjust enrichment - is not a tortious claim.'

${ }^{98}$ See text to n. 77 above.

${ }^{99}$ As noted in Graves v Graves [2007] EWCA Civ 660, at [47]; Esperance Cattle v Granite Hill [2014] WASC 279, at [455]; Bonnie Blair v Witmore [2015] HKDC 87, at [21]; Hampton v BHP Billiton [2012] WASC 285, at [358].
} 
the calculation of C's loss if a claim had been made for damages to compensate $\mathrm{C}$ for the loss of profits it would have made from using the land. ${ }^{100}$

An essential first step when quantifying any award of restitutionary damages is to identify D's gain and, as we have said already, there are two main possibilities in trespass cases. In every case, $\mathrm{D}$ acquires factual control of the land, and in most cases that is the only benefit $\mathrm{D}$ acquires, because in most cases $\mathrm{D}$ uses C's property to live in and not for business purposes. In some cases, however, $\mathrm{D}$ also receives another type of benefit, namely the profits generated by D's use of the property, and it is conceivable that in such cases, D might also make further gains, e.g. by using rental income to buy assets which increase in value. Whichever benefits are the subject of a claim, several questions might then arise: ${ }^{101}$ whether there is a sufficient causal link between D's gain and D's wrong for D to be legally liable for her gain; whether the gain is too remote a consequence of the wrong for this to be fair to D; and how D's gain should be valued. There are few cases in which these questions have been addressed, but there are some, and approaches to answering these questions have also been proposed by scholars.

First, where the benefit acquired by D was factual control of C's land, application of a "but for" causation test will often produce a justifiable result that D must pay for this benefit because $\mathrm{D}$ could not have acquired it for free if she had not wrongfully occupied C's land. However, where the claim relates to the profits of use derived by D from third party receipts, causation issues may be more complex because the question may arise whether D's profits derived from D's trespass alone or whether D's non-tortious conduct also contributed, in which case, and possibly depending on the quality of D's conduct, forcing D to disgorge all of her profits might be unfair and the award should be reduced either by apportioning the profits between tortious and non-tortious causes or by making D liable for all of the profits but allowing her to set off the value of her non-tortious input. ${ }^{102}$ The use of a "but for" causation test may also produce the "wrong" result if D can show that she would have acquired the gain by non-tortious means if she had not trespassed on C's land, but considerations of fairness as between $\mathrm{C}$ and $\mathrm{D}$ dictate that $\mathrm{D}$ should be liable nevertheless, in which case a further rule might be needed to prevent $D$ from making some types of counter-factual argument. ${ }^{103}$

Second, the idea has been mooted that claims for gain-based damages should be subject to a remoteness cap because the application of the standard "but for" causation test could otherwise expose D to an unfair degree of liability. Several tests have been proposed to determine the point at which gains become "too remote" for recovery but there is no clear support for any test in the cases. The arguments have been made, first, that $\mathrm{D}$ should not be liable for gains after her "first non-subtractive receipt", ${ }^{104}$ second, that D should be liable only for gains that "arise directly from the wrongdoing" (as would be the case, for example, if D let the land to a third party in exchange for cash, but as would not be the case if D used such cash

100 (1993) 25 H.L.R. 552 (C.A.) 554. See too Cavenagh Investment v Kaushnik Rajiv [2013] SGHC 45, at [52].

${ }^{101}$ A further question is whether expenditure by D on improving C's land should be deducted from an award of gain-based damages? The reasons why this may be appropriate in some cases but not in others are well discussed by Kaye J. in Lollis v Loulatzis [2007] VSC 547, at [229]. 102 Edelman, Gain-Based Damages, 104-5; D. Friedmann, "Restitution for Wrongs: The Measure of Recovery" (2001) 79 Texas L.R. 1879, 1892-3 and 1919. Contrast K. Oliphant (ed.), The Law of Tort ( $2^{\text {nd }}$ edn. London 2007), para. 10.57, denying that any such claim should be allowed, even against a "wilful" trespasser, owing in part to the practical difficulties of calculating a fair apportionment of gains between the parties; we do not agree that rough justice is worse than no justice.

${ }^{103}$ M.P. Gergen, "Causation in Disgorgement" (2012) 92 Boston University L.R. 827.

${ }^{104}$ P. Birks, An Introduction to the Law of Restitution (Oxford 1985), 351. 
to buy shares on which dividends were paid ${ }^{105}$ ), and, third, that D should be liable for "direct" gains if her wrongdoing was "cynical" but only for reasonably foreseeable gains if she is an "innocent" wrongdoer. ${ }^{106}$ The objections can be made to these tests that their scope is unclear and their operation may produce arbitrary outcomes. Nonetheless, the view is widely held that a remoteness test is likely to be needed, and that using different tests according to the quality of D's conduct may be desirable. ${ }^{107}$

Third, there is an ongoing debate as to whether D's gain should always be valued "objectively" or should sometimes be valued "subjectively". The leading English case on this topic is Ministry of Defence $v$ Ashman. ${ }^{108}$ As we have said above, the MOD sued Mrs Ashman for trespass and sought an award of "mesne profits", calculated not by reference to its loss of profit, which would have been the amount of concessionary rent it would have charged another tenant, but by reference to her gain. The MOD argued that this should be valued by asking what rent she would otherwise have paid for equivalent property on the private rental market. Hoffmann L.J. rejected this and held that she was liable only for the amount of rent she would have paid for the council housing she would otherwise have occupied, reasoning that she would not, because she could not, have chosen to pay a higher sum. On the facts it was appropriate to take her preferences into account when valuing her gain because she had not cynically chosen to stay in the property but had been "in no position to move anywhere else". ${ }^{109}$

In an Australian case, Hampton v BHP Billiton Minerals Pty. Ltd. (No 2), Edelman J. described this decision as "problematic" and would not have followed it if he had had to make an award in the case. This was because he considered that a defendant's personal preferences are irrelevant to the valuation of a defendant's gain when awarding gain-based damages. ${ }^{110}$ Although the judge did not spell this out, it is clear from his extra-judicial writings that his reason was that he understands the "value" of benefits to be an "objective" concept, ${ }^{111}$ a view that was endorsed by Lord Reed in an English case about a claim in unjust enrichment for the value of services, Benedetti v Sawiris. ${ }^{12}$ However, the majority of the court in Benedetti disagreed and held that it is conceptually meaningful to value benefits by reference to "subjective" considerations.

Under English law, therefore, Hoffmann L.J.'s approach in Ashman remains the governing authority and it is open to a trespasser to argue on some facts that her liability for gain-based damages should be assessed at a lower amount than the "objective value" of her gain if it would unfairly deprive her of her freedom of choice to make her pay a higher sum than she would have chosen to pay for the benefit if she had not acquired it by her wrongdoing. It should be added, though, that in many trespass cases it is not unfair to make defendants pay the "objective value" of their gains because they have had a free choice whether or not to take control of the owner's land without permission, and have consciously chosen to do this rather than buying control of the land (or other land). Defendants in this position act in a morally

105 G. Virgo, "Restitutionary Remedies for Wrongs: Causation and Remoteness" in C.E.F. Rickett (ed.), Justifying Private Law Remedies (Oxford 2008), 306.

${ }^{106}$ Edelman, Gain-Based Damages, 108-111.

${ }^{107}$ But for a dissenting voice see Gergen, "Causation in Disgorgement", 855-58.

108 (1993) 66 P. \& C.R. 195, 201-202.

${ }^{109}$ Ibid., 199.

110 [2012] WASC 285, at [333]. Edelman J. is now a Justice of the High Court of Australia.

${ }^{111}$ Edelman, "The Meaning of Loss and Enrichment", esp. 235-239; J. Edelman and E. Bant, Unjust Enrichment (2nd edn. Oxford 2016), ch. 4.

112 [2014] A.C. 938, at [122]. 
blameworthy way and should not be permitted to make "subjective devaluation" arguments, as Dyson L.J. held in Shi v Jiangsu Native Produce Import \& Export Corp. ${ }^{113}$

Finally, the question arises whether claimants in trespass cases should be able to make "subjective overvaluation" arguments, i.e. to argue that the defendant's personal circumstances make controlling the land worth more to her than it is to other people, and that the higher figure is the appropriate measure of her gain? An argument like this succeeded in an Australian case, Lamru Pty. Ltd. v Kation Pty. Ltd. ${ }^{114}$ where the amount awarded included a rental premium which $\mathrm{D}$ would have been willing to pay if the parties had entered a lease, because of the special value of the property to $\mathrm{D}$ which stemmed from a saving in moving costs, among other matters. In this regard, the assessment rules governing restitutionary damages for trespass differ from the rules governing the valuation of awards made to reverse unjust enrichments, under which "subjective overvaluation" arguments are not permitted. ${ }^{115}$ As Craig Rotherham has argued, this can be attributed to the fact that the purposes of the two types of award are different: the former aim to punish and deter wrongdoers by depriving them of the fruits of their wrongdoing; the latter, to reverse transfers not because they were wrongful but for other reasons. ${ }^{116}$

\section{CONTRACTUAL PAYMENT OBLIGATIONS}

Where $\mathrm{C}$ and $\mathrm{D}$ have a contract under which $\mathrm{D}$ is bound to pay $\mathrm{C}$ a sum of money in exchange for occupying C's land, and D fails to perform, C may seek an order that D perform her primary payment obligation, or an order that $\mathrm{D}$ pay her damages for breach of this duty. Which claim $\mathrm{C}$ brings can affect the amount awarded because the assessment of debt liabilities is not subject to the same rules as govern the assessment of liabilities to pay damages for breach of contract. Contract-breakers need only pay damages for loss caused by the breach on a "but for" test (and where the loss has multiple causes, by asking as well whether the breach was an "effective" or "dominant" cause ${ }^{117}$ ). Contract damages are also subject to the remoteness cap established by Hadley $v$ Baxendale: loss is recoverable only if it arises "according to the usual course of things" or was reasonably within the parties' contemplation at the time they made the contract as the "probable result of a breach". ${ }^{118}$ Neither rule affects claims in debt, to which it is no answer, for example, that $\mathrm{C}$ would have suffered the same loss even if $\mathrm{D}$ had paid the money.

In both types of case, the amount awarded will also be affected by a factual question: whether the parties agreed that D would pay a certain sum or an unspecified "reasonable" sum, and, if the latter, how much the parties would have thought "reasonable". The first possibility is illustrated by Uzun $v$ Ramadan. ${ }^{119} \mathrm{C}$ entered negotiations with $\mathrm{D}$ for the grant of a fixed term lease of a restaurant. Before negotiations were concluded, C took possession with D's consent. The parties agreed that $\mathrm{C}$ would pay $£ 200$ per week in rent. However, negotiations for the formal grant of a fixed term tenancy broke down because the parties failed to agree on the

113 [2009] EWCA Civ 1582, although the case had been pleaded as a claim to recover compensatory damages, rather than a claim for gain-based damages, leading Dyson L.J. to hold that D's "subjective devaluation" argument was irrelevant anyway. For further discussion of this topic, see C. Rotherham, "Subjective Valuation of Enrichment in Restitution for Wrongs" [2017] L.M.C.L.Q. 412.

114 (1988) 44 N.S.W.L.R. 432.

115 See the text to $n .136$ below.

${ }^{116}$ Rotherham, "Subjective Valuation of Enrichment in Restitution for Wrongs", 430-34.

117 Galoo Ltd. (in liq.) v Bright Grahame Murray (a firm) [1994] 1 W.L.R. 1360, 1374-75

(Glidewell L.J.) (C.A.).

118 (1854) 156 E.R. 145, 151.

${ }^{119}$ [1986] 2 E.G.L.R. 255 (Q.B.). 
length of the term. C failed to pay $£ 200$ per week and D changed the locks. C brought an action for trespass and D counterclaimed for payment. Sir Douglas Frank Q.C. rejected C's contention that he had a periodic tenancy, holding that $\mathrm{C}$ had occupied the restaurant as a tenant at will. On the counterclaim, the judge awarded D " $£ 2,640$ for use and occupation, that is, in respect of the unpaid amount of $£ 200$ a week." 120 This was framed as an award of damages but the amount awarded would have been the same if $\mathrm{C}$ had brought a claim for an agreed sum. ${ }^{121}$

Where the evidence is strong enough to identify a particular sum agreed by the parties, it is often also true that the evidence will support a finding that the parties intended to enter a contract. Where the evidence suggests that the parties had a common understanding that D would occupy the property in exchange for a payment of some sort, but it is not possible to say how much, then it is likely that they intended D to pay C a "reasonable amount", and the court must then decide how much that would have been. In such cases, the evidence may or may not be strong enough to support a finding that the parties had a contract. If it is, the court may hold that there was an implied agreement to pay, in which case the claim will be contractual; if not, then the court may still find D liable to pay, but C's claim will lie in unjust enrichment. Distinguishing these two types of case can be difficult, but it is important to be clear which type of claim is being made because different rules govern the process by which a "reasonable sum" is assessed for the purposes of each claim.

Claims in unjust enrichment are examined below in Part IV. Here we discuss three cases where the courts had to identify the amount of a "reasonable sum" payable under a contract. The first is Elgar $v$ Watson. ${ }^{122} \mathrm{C}$ owned apartments in the Isle of Wight. The parties agreed that $\mathrm{D}$ would rent these for 2 months at 8 shillings a week and that afterwards the tenancy could continue if $\mathrm{D}$ wished, but in that case a higher rent would be payable. The amount of this was not agreed. D remained in occupation for another 4 months and said that he was entitled to do so at the original rent. This was rejected by Coleridge $\mathrm{J}$. who held that the jury was entitled to find that 14 shillings a week had been a reasonable sum for the extra 4 months because these months fell in the holiday letting season. The judge said that:

generally speaking, in the absence of any new contract, the old continues; but if here, the facts and previous circumstances exclude the former agreement from attaching to the subsequent holding, I think the terms of a new tenancy remain open, and then, no new arrangement having been made, it is for the jury to say what was a fair sum to be paid under that new holding. ${ }^{123}$

The second case is Mayor of Thetford $v$ Tyler. ${ }^{124} \mathrm{C}$ owned a pub which it leased to D's mother. D took over the tail end of this lease following his success in a bidding process under which he offered to pay a larger rent under a new lease when the old lease came to an end. However, this offer was contingent on repairs being done and $\mathrm{C}$ failed to carry these out straight away. After the old lease determined, D remained in occupation and the repairs were eventually done, but there was no agreement as to the amount that $\mathrm{D}$ should pay for his use and occupation before the repairs were done. Alderson B. directed the jury to determine the amount of this and the jury held that $\mathrm{C}$ should pay less than had been due under the old lease because a reduction should be made to reflect the dilapidated state of the premises. This was confirmed by the Court

\footnotetext{
${ }^{120}$ Ibid., 258.

${ }^{121}$ Cf. Reichman v Beveridge [2006] EWCA Civ 1659, [2007] 1 P. \& C.R. 20.

122 (1842) 174 E.R. 605.

${ }^{123}$ Ibid., 605

124 (1845) 115 E.R. 810. See also Smith v Eldridge (1854) 139 E.R. 412.
} 
of Queen's Bench, Lord Denman C.J. stating that "he who holds my premises without an express bargain agrees to pay what a jury may find the occupation to be worth". ${ }^{25}$

Lastly, Dean and Chapter of Canterbury Cathedral $v$ Whitbread plc ${ }^{126}$ also concerned a pub, let by $\mathrm{C}$ for a term of 21 years. By the time the lease terminated the annual rent payable by $\mathrm{D}$ was $£ 27,500$. The parties spent the next 6 months unsuccessfully negotiating terms for a new lease, after which D said it wished to give back possession and the parties entered negotiations regarding the amount which D should pay for the holding over period. This second set of negotiations also failed. D vacated the property and a third party took possession as the new tenant at an annual rent of $£ 50,000$. $C$ brought a claim for payment arguing that the amount due for the holding over period should be calculated by reference to the new lease, i.e. the rate should be set at $£ 50,000$ p.a., or at this rate with appropriate discounts. D argued that the rate should be calculated by reference to the old lease, i.e. $£ 27,500$ p.a.

His Honour Judge Cooke held that that the amount payable during the holdover was $£ 43,560$ p.a. He took the terms of the new lease as his starting point but discounted the amount due to reflect the fact that D had not obtained a long lease, nor even a 12-month lease without security, and had merely been a tenant at will. At the same time, however, a further adjustment was needed to reflect the fact that D's control of the premises had enabled D to use them for business purposes which could not have been carried on elsewhere. The two cases noted above were cited by D's counsel for a rule that in holding over cases, "unless there is agreement to the contrary, the old rent applies". ${ }^{127}$ But the judge rejected this, remarking that in both cases "there was no enforceable agreement as to the new rent and the matter was properly left to the jury to fix it". ${ }^{128}$ Instead, he held, the cases disclosed a different rule:

[Where] there is no evidence that the parties actually agreed anything, but nothing was said on either side to depart from the proposition that the old rent ... should apply ... the court will presume from the parties' silence that they accepted that obvious proposition. ... [To] rebut the presumption [there must] be evidence that shows that the parties disagreed or, of course, agreed something else. But to my mind disagreement will do. ... [If] the parties were in disagreement with each other, and one of them at least was in disagreement with the proposition that the old rent should be the rent payable, then the presumption does not apply and the value is, as it were, for the jury. ${ }^{129}$

\section{RESTITUTION OF UNJUST ENRICHMENT}

Claims in unjust enrichment are subject to various rules which could affect the amount of a restitutionary award in C's favour. Some concern the valuation of D's enrichment and others give content to the principle that D's enrichment must have been gained "at C's expense". The main types of benefit that D might have gained in a "mesne profits" case are the factual control of C's land and profits made by D from using the land. Conceivably, D might also make "secondary gains", e.g. by using profits to buy an asset which itself generates income and/or increases in value, although as we shall discuss below, it may be impossible to claim such "secondary gains" owing to the rule that benefits must have been received "at C's expense". The first two benefits were distinguished in Lewisham L.B.C. v Masterson, ${ }^{130}$ where a claim

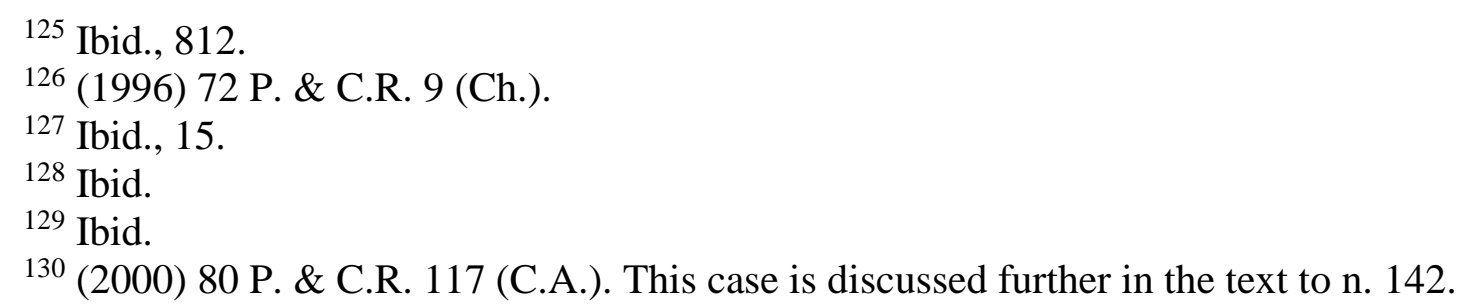


was made for the gain made by D by taking control of C's land. Buxton L.J. held that there was a difference between this benefit and "the use that ... [D] put the property to", meaning the profits of D's use; and since the claim was for the first type of benefit and not for the second, it was "nothing to the point" that D's use "was not fruitful commercially". ${ }^{131}$

The rules governing the valuation of benefits for the purposes of a claim in unjust enrichment were laid down in Benedetti v Sawiris. ${ }^{132}$ The Supreme Court justices all held that courts should start by identifying the objective value of the relevant benefit, measured by reference to its "market price" where possible. ${ }^{133}$ The judges also agreed that it could be unfair to order D to make restitution of this sum if that would effectively force her to buy the benefit at the market price if she would not have chosen to do so. According to Lord Clarke, speaking for the majority, D should not have to pay more than the sum she would have chosen to pay because this is what the benefit was "subjectively" worth to her. ${ }^{134}$ Lord Reed disagreed with this explanation, ${ }^{135}$ but agreed with the conclusion. The judges also agreed that however one characterises the principle which lets defendants escape paying the objective value of benefits where they would only have chosen to pay a smaller amount for these, it does not follow from this principle that defendants should have to pay a larger amount than the objective value where they would have been willing to pay more. ${ }^{136}$ In the first type of case, the law caps a defendant's liability at the amount she would have chosen to pay in order to protect her freedom of choice. This freedom would not be protected in the second type of case by making her pay more than the objective value of the benefit that she would have needed to pay, since she would never have chosen to pay more than she needed to pay.

In "mesne profits" cases litigated as claims in unjust enrichment, there is unlikely to be argument about the valuation of D's enrichment where this is money received by D from third parties: the value of D's enrichment is simply the face value of the money and no court is likely to be persuaded that money is worth less than its face value to D. However, valuation issues could be more complex where D's enrichment is the control of C's land. One reason is that the court in Benedetti held that when determining the objective "market value" of benefits the question to be asked is what price "a reasonable person in the defendant's position would have had to pay"? ${ }^{137}$ Usually this will be the same price as anyone else and so evidence establishing the general market rental value of the property will be the only evidence that a court needs to consider. ${ }^{138}$ According to Benedetti, though, a defendant's personal characteristics might sometimes mean that she would be charged more or less than other people to acquire the benefit, and in such a case, "the objective value of the benefit to any reasonable person in the

${ }^{131}$ Ibid., 123. See too Dream Property Sdn. Bhd. v Atlas Housing Sdn. Bhd. [2015] 2 M.L.J. 441 (Fed. Ct. of Malaysia), at [146]-[150].

132 [2013] UKSC 50, [2014] A.C. 938.

${ }^{133}$ Ibid., at [15]-[16] and [182]-[183].

${ }^{134}$ Ibid., at [12]-[26]. See too Sempra Metals Ltd v IRC [2007] UKHL 34, [2008] A.C. 561, at [119] (Lord Nicholls).

${ }^{135}$ Ibid. at [122], stating that the value of benefits can only be assessed "objectively" and the reason why D's liability should be reduced is not that the benefit is worth less to her than it is to others but that making her pay this sum would unfairly deprive her of her freedom of choice. Discussion in C. Mitchell et al. (eds.), Goff \& Jones: The Law of Unjust Enrichment $\left(9^{\text {th }}\right.$ ed London 2016), paras 4.19-4.23.

136 [2014] A.C. 938, at [27]-[30], [120]-[121] and [193]-[200].

137 Ibid., at [17] (Lord Clarke).

${ }^{138}$ Docklock Ltd. v C Christo \& Co. Ltd. [2021] EWHC 308 (Ch), at [130]. For discussion of the evidence typically used to establish this in trespass claims for compensatory damages see the text to nn. 52-67. 
same (unusual) position" as the defendant could be higher or lower than it would be to others. ${ }^{139}$ Suppose, for example, that $\mathrm{D}$ is a retail company which can negotiate cheaper rents than other tenants of premises in shopping centres because it is seen by landlords as a "key tenant". The objective value of the control of premises in a shopping centre owned by $\mathrm{C}$ could then be lower for D than for other occupants. Conversely, if D has a poor credit history, so that a landlord would be willing to let premises to D only at an elevated rent, if at all, the objective value of the benefit could be higher for D than for other people. ${ }^{140}$ In both types of case, one might say that there is, in effect, "one market for [D] and another for everyone else". ${ }^{141}$

To determine the general market value of benefits, the courts typically look at evidence of the prices paid by other people for similar or analogous benefits, but in some cases no such evidence is available, for example because the benefit received by $\mathrm{D}$ is idiosyncratic and no one other than D has evinced any interest in acquiring the benefit. In such a case, if the parties themselves agree a price for the benefit, although they never make a binding contract under which $\mathrm{D}$ is bound to pay this price, the court might regard the price agreed by the parties as the best available evidence of the benefit's objective value. Lewisham L.B.C. v Masterson ${ }^{142}$ was a case of this kind. For a five-year period, D occupied a derelict builder's yard owned by C. They pursued desultory negotiations for the grant of a 15-year lease and agreed to a rent of $£ 2,900$ p.a., but failed to agree other terms and the lease was never granted. $\mathrm{C}$ brought a claim for payment the basis of which was not made clear, but since D had C's permission to occupy the land (so that there was no trespass), and since the court accepted counsel's submission that "the principle of valuation for use and occupation [is] now seen to be a principle of restitution", ${ }^{143}$ it appears that the claim was based on unjust enrichment rather than contract. The trial judge held that the rent agreed during the parties' negotiations was evidence from which he could draw inferences about how much control of the yard was worth, particularly given that no one other than $\mathrm{D}$ had wanted to acquire this benefit. He concluded that $\mathrm{D}$ was therefore prima facie liable to pay $£ 14,500$ ( 5 years $x £ 2,900$ p.a.) but he deducted $£ 2,900$ from this sum to reflect the costs incurred by $\mathrm{D}$ in clearing the site.

The parties appealed and cross-appealed. D said that the rental sum agreed by the parties in negotiations was not evidence from which the judge could have inferred the value of D's enrichment. The parties had not entered a contract but if they had then it would have been for a 15-year lease, and not for a tenancy at will, which was effectively what D had obtained. Moreover, D would not have incurred the costs of clearing the site if he had known that he would not acquire a right to occupy the property under a 15-year lease. C supported the judge's use of the agreed rental sum to quantify D's enrichment, but argued that the judge had erred in deducting the costs of clearing the site from the award because D had not been obliged to do this and had acted for his own benefit. The Court of Appeal rejected D's appeal and allowed C's counter-appeal. Buxton L.J. upheld the judge's approach to quantification and rejected D's argument that the rent agreed by the parties in negotiations had "contemplated a situation sufficiently different from what [D] in fact obtained" for this to be disregarded as "a true guide to what the only candidate in the open market assessment was prepared to pay." 144

139 [2014] A.C. 938, at [17] (Lord Clarke). See also [22], [101]-[103], [107], [136], [184] and [186] where Lord Clarke, Lord Reed and Lord Neuberger all explained the award which had previously been made in Sempra in these terms.

${ }^{140}$ Cf Kowalishin v Roberts [2015] EWHC 1333 (Ch).

141 [2014] A.C. 938, at [17] (Lord Clarke), approving Goff \& Jones, para. 4.10.

142 (2000) 80 P. \& C.R. 117 (C.A.).

143 Ibid., 122.

${ }^{144}$ Ibid., 123. 
If the terms agreed by parties in negotiations can be relevant when valuing the control of land, there are even stronger reasons to take account of the terms of an apparently valid agreement entered by parties which is actually void. These were the facts of Ovidio Carrideo Nominees $v$ The Dog Depot Pty. Ltd., ${ }^{145}$ a case in the Victoria Court of Appeal. It concerned a lease agreement which both parties thought was valid, but which was void for non-compliance with the Retail Tenancies Reform Act 1998 (Vic.). On discovering this, the tenant sought to recover its payments on the ground that these had been made in the mistaken belief that the money had been due. The court denied recovery, reasoning among other things that the landlord had a counterclaim in unjust enrichment for the control of the property which the tenant had acquired. The value of this benefit was held by Chernov J.A. to be "broadly equal to the rent reserved under the lease". ${ }^{146}$ Nettle J.A. agreed, holding that "in formulating his claim the tenant must allow for a reasonable satisfaction" for the benefit it had received, ${ }^{147}$ and that the terms of the supposed lease were evidence of what the parties considered a reasonable sum. ${ }^{148}$

Might circumstances ever arise where it is appropriate to let D "subjectively devalue" the control of land in line with the principles which have been described here? It is generally agreed that defendants can make arguments of this kind only where they would otherwise unfairly be deprived of their freedom of choice whether to buy the relevant benefit at the market price. This condition will not be satisfied on the facts of many "mesne profits" cases which might be pleaded as claims in unjust enrichment because these will possess the features, first, that $\mathrm{C}$ intends $\mathrm{D}$ to acquire control of C's property only if $\mathrm{D}$ pays the market price for this benefit, second, that $\mathrm{D}$ knows this to be the case, and, third, D chooses to take the benefit on that basis. "Subjective devaluation" arguments will be open to D only where these features are not present, as might be the case, for example, where the parties are at cross-purposes and D incorrectly believes that $\mathrm{C}$ intends to let $\mathrm{D}$ acquire control of the land in exchange for payment of a lower amount or for free.

Turning to the rule that D's enrichment must have been gained "at C's expense", the Supreme Court held in Prudential Assurance Co. Ltd. v H.M.R.C. ${ }^{149}$ that claims in unjust enrichment lie only where there has been a "transfer of value" between $\mathrm{C}$ and $\mathrm{D},{ }^{150}$ and where $\mathrm{D}$ has acquired a benefit "directly" from $\mathrm{C} .{ }^{151}$ Where a claim is made to recover for the factual control of C's land, one might wonder as a matter of abstract principle and everyday language whether this control has been "transferred" from $\mathrm{C}$ to $\mathrm{D}$ and one might also wonder as a matter of law whether D has acquired this benefit "directly" from C and not, for example, "indirectly" through D's own actions in occupying the property and failing to pay for this. As a matter of authority, however, these doubts may be put to one side following Foxton J.'s decision in School Facility Management Ltd. v Governing Body of Christ the King College $e^{152}$ that the "at the expense of" requirement is satisfied in such cases, at least where control of the property is the only benefit claimed, and is not tacked on as an added extra to a claim to recover title.

145 [2006] VSCA 6, [2006] V Conv R 54-713. See also De Medina v Polson (1815) 171 E.R. 157, 157 (where the parties' lease agreement was void under the Statute of Frauds but its terms could nevertheless be consulted to determine the value of D's occupation).

${ }^{146}$ Ibid., at [22].

${ }^{147}$ Ibid., at [49].

${ }^{148}$ Ibid., at [50].

149 [2018] UKSC 39, [2019] A.C. 929.

${ }^{150}$ Ibid. at [68], following Investment Trust Companies v HMRC [2017] UKSC 29, [2018] A.C. 275 , at [42].

${ }^{151}$ Ibid. at [71]-[74].

152 [2020] EWHC 1118 (Comm), [2020] P.T.S.R. 1913 at [437]; not considered on appeal: [2021] EWCA Civ 1053. 
However, it may still be that the "direct transfer" rule cannot be satisfied where D's enrichment is a "secondary gain" of the kind described above. Whether or not such a benefit is recoverable depends on the meaning of the "direct transfer" rule, but the reasoning in Prudential suggests that it may not be because the direct cause of $\mathrm{D}$ acquiring it is not a receipt from C, but D's own actions in buying a new asset with money acquired by using C's land. It is questionable whether the Supreme Court intended its decision to produce such a result, and if this is the rule that would apply in such a case, whether it is well justified in principle.

\section{CONCLUSION}

This article continues the argument of an earlier associated article that cases where "mesne profits" awards have been made are often misunderstood because it is not generally appreciated that they variously rest on different causes of action, leading to the award of different remedies. One reason why courts and scholars have been slow to recognise this is that the facts of many cases have been such that the same result would have followed, whether the case had been pleaded in tort, contract or unjust enrichment, and whether the remedy awarded had been focussed on C's loss, D's gain or something else. Examples of this have been given throughout the present article, but so too have examples of the opposite phenomenon, that the facts of other cases are such that different results would have followed depending on the pleading of the case, either because some types of claim would not have succeeded at all or because different claims would have been viable but would have led to different outcomes because different assessment rules would have applied depending on the nature of the claim and the nature of the remedy.

Most of the remedies awarded in the "mesne profits cases" have C's loss and D's gain as their focus, although some do not because they are orders to perform a contractual payment obligation. Regarding the cases where the remedy awarded is focussed on loss or gain, we have stressed that there is more than one type of benefit that $\mathrm{C}$ may have lost and $\mathrm{D}$ may have gained, and we have argued that there is no hope of understanding the law unless this is recognised and the differences between these benefits are understood. Once the loss or gain which is the subject of a claim has been identified the question must be addressed, of how the loss or gain should be valued. The English cases concerning claims for restitutionary damages in tort and claims in unjust enrichment envisage that an "objective" approach should usually be taken when valuing D's gain, asking what a reasonable person in D's position would have paid for the benefit, but they also hold that a "subjective" approach is sometimes appropriate, asking what D herself would have been willing to pay for the gain if she had not acquired it for free as a result of her wrong or her unjust enrichment.

As Daniel Friedmann has observed, there is also a sense in which it can be said that "objective" and "subjective" approaches are taken to the valuation of C's loss when quantifying awards of compensatory damages in tort and breach of contract. An "objective" approach that identifies the market value of C's loss may produce the same sum as an exercise in quantifying the "objective" value of D's gain where C's loss and D's gain are flip sides of the same coin, something which can be said of many cases concerning control of property. But as Friedmann also writes, "whether this seeming equality indeed reflects the legal position depends on rules relating to assessing damages, on the one hand, and those relating to measuring the enrichment on the other." 153 On a "subjective" approach to the valuation of loss, factors may be taken into account which are peculiar to $\mathrm{C}$ and either increase or decrease the loss suffered by her, producing a different amount from the valuation of D's gain. And as a general rule:

${ }^{153}$ D. Friedmann, "Restitution for Wrongs: The Measure of Recovery" (2001) 79 Texas L.R. $1879,1880$. 
the initial approach of Anglo-American law is that damages are compensatory and, consequently, that the plaintiff is entitled to recover the losses that he suffered as a result of the wrong. Prima facie, this leads to the ["subjective"] measurement (hence the "thin skull" rule in torts). However, this approach is severely limited by the rules on mitigation and causation (remoteness of damages) and the date for the assessment of damages. These rules tend to render the assessment of damages more objective and less dependent upon the subjective elements of the plaintiff. ${ }^{154}$

So, for example, in a case where $\mathrm{C}$ is wrongfully kept out of possession of land, she might claim compensation for her loss of control and if the court took a purely "subjective" approach, it would let $\mathrm{C}$ recover the value of this benefit to her, assessed by asking how much she would have been willing to pay for it. Depending on the facts, that might conceivably result in the award of a sum higher than the open market rental value of the land, for example because $\mathrm{C}$ had a special need for the land, so that losing control of it was unusually expensive for her. Also depending on the facts, however, the court might hold that fairness to D required a more "objective" approach to be taken and reduce the award, for example, because the "extra" loss to $\mathrm{C}$ was too remote a consequence of D's wrongdoing, because it was not reasonably foreseeable to $\mathrm{D}$ that $\mathrm{C}$ would suffer it, or because $\mathrm{C}$ could reasonably have mitigated her loss, for example, by renting alternative property for a lower amount.

${ }^{154}$ Ibid., 1882. 